Cipango Cahiers d'études japonaises

Hors-série | 2008

Autour du Genji monogatari

\title{
Texte et prétexte
}

Traduire le Genji en langue moderne

Text et pretext: Genji's translations in modern language

\section{Anne Bayard-Sakai}

\section{(2) OpenEdition}

Journals

Édition électronique

URL : https://journals.openedition.org/cipango/600

DOI : $10.4000 /$ cipango.600

ISSN : 2260-7706

Éditeur

INALCO

Édition imprimée

Date de publication : 1 janvier 2008

Pagination : 155-182

ISBN : 978-2-85831-170-5

ISSN : 1164-5857

Référence électronique

Anne Bayard-Sakai, « TEXTE ET PRÉTEXTE », Cipango [En ligne], Hors-série | 2008, mis en ligne le 10 juin 2012, consulté le 30 juin 2021. URL : http://journals.openedition.org/cipango/600 ; DOI : https:// doi.org/10.4000/cipango.600

Ce document a été généré automatiquement le 30 juin 2021.

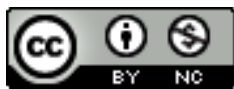

Cipango est mis à disposition selon les termes de la Licence Creative Commons Attribution - Pas d'Utilisation Commerciale 4.0 International. 


\title{
Texte et prétexte
}

Traduire le Genji en langue moderne

Text et pretext: Genji's translations in modern language

\author{
Anne Bayard-Sakai
}

1 Si on interrogeait les lecteurs d'aujourd'hui sur ce qu'est le Genji monogatari, certains pourraient être tentés de répondre, non sans une pointe d'ironie : le chef-d'œuvre de Setouchi Jakuchō. Traduire un classique en langue moderne est en effet un acte littéraire ambivalent. Par la traduction, le texte classique est conforté dans sa valeur canonique et constitutive d'une tradition qui ne peut exister sans lui; dans le même mouvement pourtant, par cet acte qui conforte sa légitimité, il est rendu étranger à luimême, potentiellement capté par un traducteur qui s'appropriera son prestige classique tout en le transformant en autre chose. Il sera donc ici question du statut et de la signification d'un certain nombre de ces actes ambivalents, de ces traductions modernes du Genji monogatari d'un genre un peu particulier: non pas de n'importe lesquelles de ces traductions récentes ${ }^{1}$, mais de celles que l'on doit à des écrivains, et qui s'inscrivent donc dans les bibliographies à un double titre littéraire - en tant que traductions du Genji, et en tant qu'œuvres d'un écrivain, plus précisément d'un romancier. Des textes, ainsi, pour lesquels le nom d'un romancier moderne vient se surajouter à celui de Murasaki Shikibu.

2 La distinction traductions savantes/traductions littéraires mérite que l'on s'y arrête un instant. Il n'est pas question ici des qualités littéraires que la critique ou les lecteurs reconnaissent de fait à telles ou telles traductions, mais des intentions affichées, auxquelles répond une certaine attente des lecteurs. La traduction savante (que l'on trouve parfois glosée comme «traduction que l'on doit à des spécialistes de littérature nationale » (kokubungakusha no yakubun 国文学者の訳文) aura comme but, au moins officiel, l'explicitation du texte de départ à travers la traduction, et non l'expression de la personnalité, ou de la vision du monde, ou de la vision de la littérature, de son auteur. Elle sera donc évaluée à l'aune de sa précision et de sa pertinence ; elle sera lue en même temps que les notes qui sont destinées à lever les obscurités et dissiper les incertitudes. Ces critères ne sont pas à l'œuvre dans l'évaluation des traductions que l'on appellera ici par commodité «littéraires». On verra comment ces traductions 
intègrent, ou n'intègrent pas, la part savante d'explicitation des textes. Mais si on apprécie telle ou telle de ces traductions littéraires, ce ne sera pas parce que l'interprétation de tel point du texte sera convaincante. Le goût, le plaisir - ou le déplaisir - sont ailleurs.

3 Ce qui nous ramène au statut ambivalent des traductions littéraires en langue moderne. D'où tirent-elles leur légitimité ? D'abord, évidemment, de leur définition même comme hypertexte, et donc, en premier lieu, d'un prestige d'emprunt qui leur vient du Genji. Mais également de la littérarité exhibée par le nom d'auteur, qui figure sur la page de couverture, et qui se trouve même parfois intégrée dans le titre ${ }^{2}$. Le lecteur qui se lance dans la lecture d'une de ces traductions choisira tout autant le Genji que le nom de l'auteur - l'auteur de la traduction. Le texte d'arrivée, dès lors, viendrait si bien couvrir l'image de l'hypotexte que de celui-là ne subsisterait plus guère, précisément, que son statut d'hypotexte. Sans doute, le Genji souffre-t-il aujourd'hui de ce basculement, dans la mesure où si ce roman, comme emblème du patrimoine littéraire national, est présent dans l'esprit des lecteurs, son existence comme texte propre disparaît peu à peu, enfouie sous les strates successives de traductions, de réécritures, de mises en images, de détournements, qui, en somme, parasitent et épuisent son prestige. Et de fait les traductions littéraires occupent une place étrange, dans laquelle elles sont dans le même temps et indissolublement à la fois dans une extrême intimité avec le texte premier, et dans une extrême mise à distance.

4 Le fait qu'un nombre non négligeable d'écrivains se soient attachés à traduire le Genji en langue moderne est ainsi significatif en soi, comme si l'étrangeté de la tâche exerçait un pouvoir de fascination. Étant donné leur nombre, nous ne pourrons ici examiner toutes ces traductions, et il nous faudra nous limiter à celles qui, au moment de leur parution, par l'alliance du prestige du texte et de celui du nom d'auteur, ont marqué leur époque d'un point de vue littéraire ou éditorial et qui, de ce fait, sont encore aujourd'hui largement diffusées en version de poche; autrement dit, aux traductions qui, par leur accessibilité, garantissent véritablement la présence contemporaine du Genji et pérennisent son statut de classique - mais immédiatement lisible pour les lecteurs actuels ${ }^{3}$. Certains d'ailleurs ont publié plusieurs versions successives que nous signalons, même si l'analyse ensuite se concentrera sur les dernières versions parues, celles donc reprises en poche. Enfin, pour prendre véritablement en compte l'actualité $\mathrm{du}$ Genji, nous devrons ajouter à notre liste la dernière version en date des traductions « littéraires » même si elle n'a pas encore paru en poche, celle qui a fait du Genji Monogatari un best-seller des temps modernes : la version Setouchi Jakuchō.

Notre corpus se compose donc ainsi :

A. Yosano Akiko :

1. Yosano Akiko yaku, Shin.yaku Genji Monogatari, Kanao Bun.endō, 1912-1913.

与謝野晶子訳、「新譯源氏物語」、明 45-大 2、金尾文淵堂刊。

2. Yosano Akiko yaku, Shinshin.yaku Genji Monogatari, Kanao Bun.endō, 1938-1939.

与謝野晶子訳、「新々譯源氏物語」、明 45一大 2、金尾文淵堂刊。

Version reprise dans d'édition de poche:

Yosano Akiko yaku, Zen.yaku Genji Monogatari, Kadokawa bunko, 1971.

与謝野晶子訳、「全訳源氏物語」、昭 46、角川文庫。

B. Tanizaki Jun.ichirō :

1. Tanizaki Jun.ichirō, Jun.ichirō yaku Genji Monogatari, Chūō Kōronsha, 1939-1941.

谷崎潤一郎、「潤一郎訳源氏物語」、昭 14-16、中央公論社。

2. Tanizaki Jun.ichirō, Jun.ichirō shin.yaku Genji Monogatari, Chūō Kōronsha, 1951-1954. 
谷崎潤一郎、「潤一郎新訳源氏物語」、昭 26-29、中央公論社。

3. Tanizaki Jun.ichirō, Jun.ichirō shinshin.yaku Genji Monogatari, Chūō Kōronsha, 1964-1965.

谷崎潤一郎、「潤一郎新々訳源氏物語」、昭 39-40、中央公論社。

Version reprise dans d'édition de poche:

Tanizaki Jun.ichirō, Jun.ichirō yaku Genji Monogatari, Chūkō bunko, 1973.

谷崎潤一郎、「潤一郎訳源氏物語」、昭 48 、中公文庫。

C. Enchi Fumiko :

1. Enchi Fumiko yaku, Genji monogatari, Shinchōsha, 1972-1973.

円地文子訳、「源氏物語」、昭 47-48, 新潮社。

Repris dans l'édition de poche:

Enchi Fumiko yaku, Genji monogatari, Shinchō bunko, 1980.

円地文子訳、「源氏物語」、昭 55 , 新潮文庫。

D. Setouchi Jakuchō :

Setouchi Jakuchō yaku, Genji monogatari, Kōdansha, 1997.

瀬戸内寂聴訳、「源物語」、平 9 , 講談社。

Que Yosano et Tanizaki aient publié plusieurs versions est, en soit significatif. Leurs choix de traduction ont, en effet, varié avec le temps, soit pour des raisons éditoriales et littéraires, soit pour des raisons plus politiques.

Prenons d'abord le cas de Yosano. La première version n'est pas exhaustive, et il s'agit bien plus en réalité d'une adaptation voire d'un résumé que d'une traduction. Les poèmes, en outre, sont traduits et reformatés en poèmes de cinq lignes. La deuxième version en revanche, comme l'indique d'ailleurs le titre de l'édition de poche (zen.yaku), est intégrale ; certes, on peut noter des omissions sur des parties de phrases, mais non sur des passages entiers. Les poèmes, cette fois, sont cités et non traduits.

Le cas de Tanizaki se présente très différemment. La première version, publiée en pleine guerre, est marquée par un choix stylistique - l'exposition en style -de aru-, et par une nécessité politique: la relation du Genji avec Fujitsubo est absente de la traduction. La deuxième version, publiée après guerre, rétablit les épisodes absents et opte pour le style en -desu/-masu. La troisième version est très proche de la deuxième, si ce n'est qu'elle adopte le nouveau système graphique, shin kanazukai 新仅名遣い, et c'est donc celle-ci que nous pouvons lire aujourd'hui en version de poche.

Avant d'aborder la spécificité des choix d'écriture de chacune de ces versions actuelles du Genji, examinons la manière concrète, pour ainsi dire matérielle, dont ces textes se rapportent à l'hypotexte. La traduction en langue moderne d'un classique tel que le Genji exige en effet que soient pris deux types de décision, l'un à propos de l'explicitation des éléments opaques du texte, l'autre à propos du traitement des poèmes qui ponctuent la narration.

10 La distance temporelle et historique qui nous sépare de l'élaboration du Genji est, bien évidemment, génératrice d'opacité. Des faits de civilisation peuvent nous être étrangers, des allusions incompréhensibles, des références inintelligibles - sans même mentionner les passages obscurs du texte lui-même. Dans ces traits d'opacité, les traductions savantes, en somme, puisent leur raison d'être : elles ont pour objectif de les dissiper grâce à un appareillage de notes ou de glose, d'expliquer ces faits de civilisation, d'éclairer les allusions, de préciser les références ${ }^{4}$. Le traitement des poèmes est inséparable de cette mission d'éclaircissement, et les notes ont à la fois une fonction d'aiguillage sémantique - elles donnent la signification des poèmes - et d'explicitation philologique - elles donnent les références et analysent la structure 
grammaticale et poétique du poème en précisant par exemple le fonctionnement des mots-pivots.

11 Les traductions littéraires sont, bien entendu, confrontées aux mêmes opacités de l'hypotexte. Or on constate que chacune des traductions opte pour des solutions, ou des absences de solution, différentes.

La version Yosano est, incontestablement, la plus insouciante de l'inconfort du lecteur, la plus brutale en ce sens dans la confrontation avec l'hypotexte. Aucune allusion n'est explicitée, aucune référence n'est donnée, et ce qui doit être compris par le lecteur l'est par une intégration, qui peut parfois être quelque peu paraphrastique, dans le corps du texte. On ne s'étonnera donc pas que les poèmes soient simplement cités, sans aucune explication et sans traduction en langue moderne. Ce dernier choix est d'autant plus intéressant que Yosano Akiko est la grande poétesse que l'on sait, dont la contribution au passage du tanka à la modernité fut décisive; elle aurait pu traduire, se dit le lecteur... Mais précisément, c'est sans doute la conscience de la distance infranchissable qui sépare du tanka moderne le waka classique ou, plus précisément, le waka inséré dans la prose classique, qui l'a fait renoncer à proposer une transposition en langue moderne. Et dès lors qu'est radical son choix d'une traduction non savante, il est logique que les poèmes ne soient pas plus référencés et explicités que le reste de la narration ${ }^{5}$.

13 Enchi Fumiko opte, pourrait-on dire, pour une solution intermédiaire. Si aucun éclaircissement, aucune explicitation ne sont proposés au lecteur, les poèmes en revanche font l'objet d'un double traitement: ils sont cités dans le texte, et accompagnés d'une traduction très sommaire en langue moderne placée à la gauche des pages de gauche. Cette traduction se contente de reprendre un sens premier, élémentaire, et ne s'encombre pas d'échos sémantiques ou poétiques; elle est résolument narrative, et ne se soucie guère de se donner une apparence poétique. Ainsi, le poème suivant, qui figure dans le chapitre Suma :

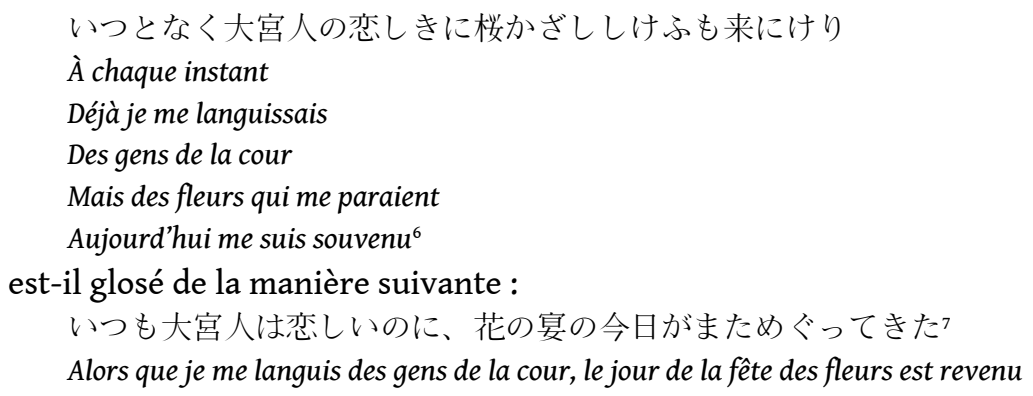

Que le lecteur y ait gagné quelque chose dans sa compréhension intime du poème reste douteux, mais au moins un sens lui est-il proposé, intégrable dans sa lecture cursive, alors que le poème simplement cité risque de demeurer comme un point d'opacité. Il faut ajouter à cela que parfois le choix de ne pas vouloir donner un air poétique à la traduction du poème a des résultats éminemment... prosaïques; on en veut comme exemple le poème de Murasaki no ue qui se trouve au début du chapitre Akashi :

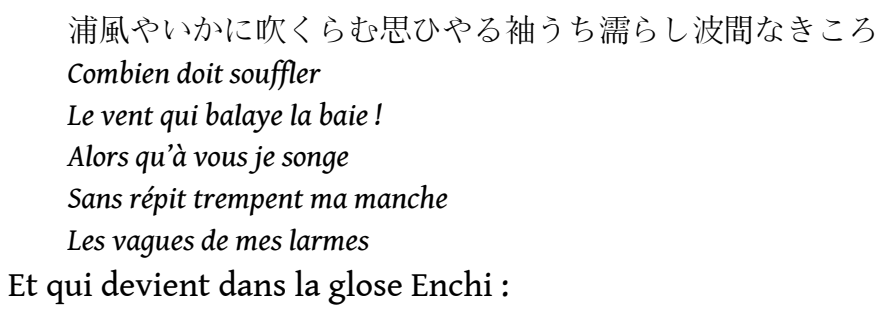


私は絶え間なく泣き暮らしていますが、そちらは天候はいかがでしょうか8

Tandis que je passe mes jours à pleurer, quel temps fait-il près de chez vous?

La solution de Setouchi Jakuchō n'est pas fondamentalement différente de celle d'Enchi. Une « explicitation des mots et expressions » (goku kaishaku 語句解釈) placée à la fin de chaque volume et qui n'est pas de la main de Setouchi ${ }^{9}$ fait office de glossaire et explicite quelques allusions, mais pas de manière systématique. Les poèmes, quant à eux, sont cités et accompagnés, dans la partie inférieure de la page et avec une casse plus petite, d'une traduction qui glose en cinq vers. Ainsi, le poème du chapitre Suma déjà cité devient, glosé par Setouchi :

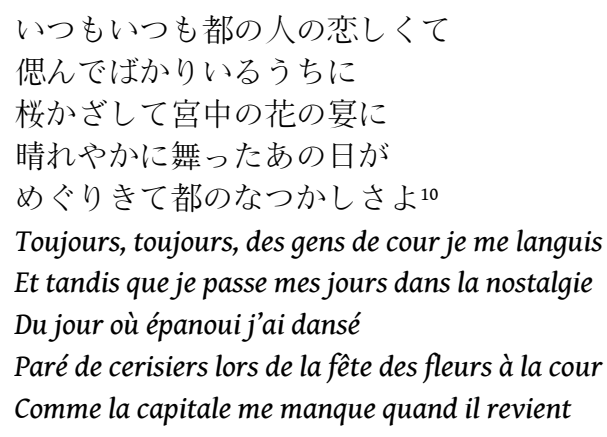

En somme, les choix de Setouchi donnent à la lecture l'impression d'être hybrides, comme si l'auteur n'avait pu vraiment se résoudre à ne pas se prévaloir de la place d'un sujet détenteur de savoir, d'où des ébauches d'explicitation, mais aléatoires, et une tentative pour poétiser les traductions de poème, avec un résultat qui n'emporte pas nécessairement la conviction. Il faut d'ailleurs signaler que dans chaque volume, après la traduction et avant le glossaire, figure un « Guide du Genji » (Genji no shiori 源氏のし おり), signé Setouchi, qui donne des indications générales sur le Genji (pour le premier volume) et des résumés des chapitres, comme si l'auteur craignait que la traduction ne se suffise pas à elle-même et que l'histoire ne soit pas intelligible si on ne présentait en même temps au lecteur un digest.

Ceux qui connaissent Tanizaki Jun.ichirō comme inventeur de configurations romanesques ne s'étonneront pas de constater que les solutions adoptées par cet auteur sont les plus élaborées. La traduction est dotée d'un appareil critique sous la forme de notes en haut de pages, comme par mimétisme formel sur des éditions savantes. Les poèmes, cités dans le texte, sont traduits didactiquement dans cet espace, où sont données également les références. Ainsi, le même poème du chapitre Suma se trouve-t-il explicité et glosé chez Tanizaki de la manière suivante :

\footnotetext{
「ももしきの大宮人はいとまあれや桜かざして今日も暮しつ」 [古今六帖]によ

る。「自分はいつということはなく、始終大宮人が恋しいのに、昔桜の花をか

Il n'est pas absolument certain que cette explicitation soit réellement éclairante, mais le lecteur a malgré tout le sentiment que l'auteur lui livre quelques repères. De fait, les allusions poétiques sont ainsi signalées dans le texte, et les références données en haut de page. Qu'est-ce qui sépare alors la traduction Tanizaki d'une traduction savante ? Le 
degré de précision des informations. Si une référence poétique est donnée, elle le sera au recueil et non, plus finement, au chapitre, ou au poème en question lui-même. Il semble, à la lecture, que Tanizaki ait voulu en rester à une demi-mesure, ou qu'il ait voulu donner une apparence savante à sa traduction sans que le poids du dispositif de savoir vienne en définitive parasiter la traduction elle-même.

Pour résumer la question que posent ces choix et la variété des dispositifs matériels qui en résultent, on peut dire qu'il s'agit, en définitive, de la préparation dans le texte de ce que sera la lecture, de ce que l'auteur, d'une certaine manière, veut faire comprendre au lecteur, sachant que la distance avec l'hypotexte est une donnée de départ de cette lecture. Dans la version Yosano, les poèmes sont là pour figurer une poche d'incompréhension pour le lecteur, cette incompréhension permettant précisément de rappeler la distance, évidemment historique en premier lieu, avec l'original. Mais ce rappel, cette évocation, ont aussi un effet paradoxal, qui est de mieux montrer à quel point tout le reste est compréhensible et donc à quel point ce que l'on ne comprend pas a peu d'importance. Dans la version Enchi, nous avons affaire à une sorte de neutralisation de ce qui tient à l'histoire et au patrimoine littéraire : en comprenant le sens des poèmes, on peut passer à la suite, ne pas s'y arrêter, et gommer tout ce qui est allusions. Ce qui serait inintelligible se trouve masqué, il n'y a rien, en somme, à ne pas comprendre. Dans la version Tanizaki, en revanche, le fait que nous ayons affaire à un texte patrimonial est signalé avec insistance; le lecteur se voit constamment rappelé qu'il est devant un texte que traversent de part en part les références littéraires de l'époque Heian, et l'insistance de ce rappel tend à indiquer qu'il s'intègre dans le projet d'écriture en tant que tel. Trois manières, donc, de situer au sens le plus matériel du terme le texte dans l'histoire littéraire, trois manières certainement symptomatiques de ce que sont les différents textes en tant que tels.

Comment pourrait-on alors caractériser à la fois leur positionnement spécifique et leurs différences mutuelles? La question demeurera en partie irrésolue ici par manque d'éléments. Pour trancher en effet véritablement, il faudrait disposer d'informations sur les relations intertextuelles qui lient ces différentes versions, ce qui n'est malheureusement pas le cas. À n'en pas douter, des réflexions et des commentaires des auteurs les uns sur les autres, voire des échos directs d'une traduction à l'intérieur d'une autre nous apporteraient des éléments très instructifs. D'un point de vue théorique - mais que vaut alors la théorie - il est difficile de croire que l'intertextualité ne joue pas un grand rôle, ne serait-ce qu'en dessinant un genre subreptice qui serait la traduction en langue moderne du Genji, genre par rapport à quoi les uns et les autres se détermineraient en ménageant, dans chacun de leur texte, des écarts et des similitudes; toutefois, en l'absence de preuves matérielles, nous nous abstiendrons de trancher. Il faut toutefois préciser que la conscience que l'on a affaire à un genre est en tout cas présente dans la critique, bien que la bibliographie sur la question ne soit pas très abondante ${ }^{12} ;$ l'un des articles les plus pénétrants sur la question, celui de Kitamura Yuika paru en 1992 dans la revue Bungaku, nous fournira ici plusieurs éléments de réflexion ${ }^{13}$.

21 Kitamura reprend dans son analyse un schéma globalement admis qui consiste à opposer Yosano et Tanizaki. Elle cite une remarque de Nakamura Shin.ichirō qui résume de manière très parlante une différence qui frappe dès l'abord quand on se penche sur les textes en question. 
「谷崎訳は王朝物語として「源氏物語」を再現しようと努力しているのであ

り、与謝野訳は、小説として再生しようとしている ${ }^{14} 」$

La traduction Tanizaki tente de reconstituer le Genji monogatari en tant que monogatari,

alors que la traduction Yosano tente de lui redonner vie en tant que roman.

l'effet qu'obtient Tanizaki par son choix du style en -desu/-masu. C'est par excellence un style d'adresse, katarikake no buntai 語りかけの文体, que l'auteur n'utilise pas seulement pour les propositions conclusives mais aussi pour celles, subordonnées ou connectives, qui sont intérieures à la phrase. En procédant ainsi, Tanizaki pose très fortement, on serait presque tenté de dire physiquement, un interlocuteur présent, et non un destinataire abstrait qui n'est qu'une instance narrative. Le résultat est un récit éminemment à la première personne - une première personne non pas grammaticale mais énonciatrice, mené par un narrateur (très généralement) hétérodiégétique. Autre caractéristique, le rapport du temps de l'histoire et du temps du récit demeure indéterminable et changeant : rétrospectif ou - faussement - simultané. Cette sorte de labilité temporelle n'est possible que grâce à la présence de ce narrateur énonciateur, qui se déplace très librement le long du double fil temporel du récit et de l'histoire. Les choix stylistiques de Yosano la conduisent en revanche à construire une narration toute différente. Son narrateur, strictement hétérodiégétique, mène une narration de troisième personne, qui ne pose aucun destinataire présent dans la lettre du texte ${ }^{15}$; il n'y a en ce sens pas de marquage énonciatif particulier. De même que la traduction ne s'accompagne d'aucun dispositif permettant d'aider la lecture, de même le texte ne propose aucune aide au lecteur pour entrer plus facilement dans le texte par le biais d'un énonciataire auquel il pourrait s'identifier. C'est, en somme, un texte que le lecteur est invité à aborder sans médiation. De cette même caractéristique relève la temporalité du texte : le récit est clairement à l'accompli, coulé dans un passé narratif dont on aurait, pour une fois, envie de dire qu'il est tout autant passé que narratif... De ce choix, il faut enfin signaler une conséquence sur la terminaison des phrases: on relève en effet une multiplication des formes en -ta, avec un effet rythmique de martèlement.

Cette différence dans les options stylistiques fondamentales a des répercussions sur les modes de désignation des personnes. Le narrateur de Tanizaki, présent dans le texte, évite de mentionner le sujet, grammatical et acteur, de la phrase, et c'est souvent par la manière dont sont utilisés les termes dits de politesse (keigo 敬語) que le lecteur parvient à identifier les personnes en cause. Chez Yosano, le narrateur, qui est extérieur au texte, restitue beaucoup plus largement les sujets et donc recourt aux keigo d'une manière que l'on pourrait dire raisonnée. Chose notable, il n'en utilise pas quand il est question du personnage du Genji.

Comment le narrateur se désigne-t-il alors lui-même dans le texte? Une de ses interventions directes, dans le même chapitre, est significative à cet égard (voir annexe 2). 
voit que Yosano fait intervenir quelqu'un dont la définition est de coucher par écrit le récit : hissha 筆者, celui qui tient le pinceau, un scripteur, et l'omission sur laquelle il revient relève logiquement du verbe kakimorasu 書き漏らす, omettre ou négliger de transcrire. Cette caractérisation du narrateur comme scripteur est certainement celle qui le place à la plus grande distance de son texte; on pourrait même presque voir un dédoublement, le narrateur commentant un geste effectué par (lui-même en tant qu'il a été) le scripteur. Chez Tanizaki, si l'on trouve le même verbe, il est assumé à la première personne, première personne identique au narrateur et qui demeure entièrement présente dans son récit, si présente même que la phrase suivante déjà est réintégrée dans son énonciation.

La différence de positionnement des narrateurs explique alors que le rapport à la subjectivité - celle du narrateur comme celle des personnages soit si différent dans les deux versions. La toute première phrase de l'incipit en donne un exemple presque caricatural : Yosano a tendance à extérioriser, objectiver les événements (la phrase est construite autour des incidents qui deviennent de plus en plus nombreux), alors que Tanizaki centre sa phrase - en conformité avec l'original - sur les pensées du prince Genji, faisant pénétrer le lecteur dans l'intimité de sa subjectivité. Il est d'ailleurs également remarquable que le narrateur ici, comme très souvent, semble épouser les méandres des délibérations intérieures du personnage, dans des énoncés qui semblent se replier et se déplier selon son humeur et l'air du temps, alors que chez Yosano, en revanche, le narrateur rationalise le discours et ordonne les pensées qui sont présentées avec la plus grande clarté possible.

Chez Tanizaki comme chez Yosano, il est évident que les choix convergent pour obtenir un effet d'écriture et de lecture spécifique. Dans le cas de Tanizaki, tout semble dicté par la volonté de faire entendre une voix narrative ou mieux : une parole narrative ${ }^{16}$. Mais cette parole est ici surdéterminée : en l'occurrence, elle lui permet de reconstituer une situation d'interlocution particulière, celle que le lecteur doit comprendre comme constitutive du monogatari ${ }^{17}$. Tanizaki est d'ailleurs très attentif à recréer une sorte d'ambiance langagière qui rappellerait Heian : il tente, dans la mesure du possible, de garder le lexique original, de recourir, d'une façon générale, à du vocabulaire ancien, kogo 古語, et d'éviter les mots d'origine chinoise ou composés de kanji, kango 漢語 (à la différence de Yosano qui recourt largement aux kango et aux shingo 新語). On comprend alors le rôle que joue, dans cette stratégie globale, la fonction dévolue à la présentation matérielle du texte et à l'« air savant » de la traduction; il y a un effet de brouillage, le lecteur ne sait pas si c'est la traduction ou l'original qui est accompagné de notes... Si le texte mérite un appareil critique, c'est en fait parce qu'il est un monogatari, donc un texte classique, avant d'être une traduction d'un monogatari. En somme, le dispositif matériel relève d'une entreprise plus générale d'accréditation, dans lequel l'hypertexte prétend non pas tant traduire l'hypotexte que se substituer à lui - devenir lui, dans sa forme comme dans son élaboration, puisque même la parole qui l'a produit se trouve ici restituée.

Mais l'affaire se complique ici du fait que cette parole est supposée reproduire la parole du monogatari. Or il y a une facticité du choix, puisque la parole narrative que l'on entend dans la version moderne ne s'adresse pas au(x) même(s) interlocuteur(s) que la voix narrative de l'original, qu'il n'y a pas de partage d'un même champ de culture et de langage chez destinateur et destinataire - bref qu'il y a un millénaire entre l'original et la traduction. Autrement dit, le texte de Tanizaki et la situation d'énonciation qu'il 
met en écriture mime ce qui était dispositif textuel et énonciatif chez Murasaki Shikibu : il est, par le choix de cette simulation, une fiction. L'« ambiance langagière » qui nimbe le texte est, elle aussi pure fiction, n'appartenant pas plus au monogatari original que le narrateur. En ce sens, dire de la traduction Tanizaki qu'elle est fictionnelle n'a aucun sens s'il s'agit du contenu, mais le qualificatif prend tout son intérêt si on l'applique à l'énonciation elle-même.

Demeure alors une question non résolue : l'oblitération ou la prise en compte de la dimension écrite du texte ${ }^{18}$. Certes, nous lisons un texte écrit. Mais ce texte est-il supposé être lu comme une transcription simulée d'une parole préalable? Ou l'énonciation se coule-t-elle d'emblée dans une mise à l'écrit? Le verbe kakimorasu, de ce point de vue là, est intéressant, car il semble, en quelque sorte, échapper à Tanizaki, relever d'une logique étouffée du texte écrit, sachant que la formulation de l'original n'imposait pas le choix de ce verbe dans la traduction, que différentes solutions pouvaient être envisagées. Autre indice, encore : la présence du nom de l'auteur dans le titre. Comment comprendre ce Jun.ichirō yaku? Quel lien est-il ainsi suggéré entre l'auteur, dont le nom est mis en avant, et la parole, dont procède fictivement la narration? Si cette parole que l'on entend est, dans le titre même, rapportée à l'auteur qui l'a forgée dans ses mots, autrement dit si sa dimension fictionnelle est soulignée, peut-être sommes-nous en droit d'y percevoir une sorte d'aveu - aveu que l'on est dans un théâtre d'ombre, éminemment littéraire, il va sans dire.

31 Revenons alors à Yosano Akiko. Ses choix amènent, incontestablement, des effets d'écriture beaucoup plus stables, sans oscillation dans les partis narratifs. D'une certaine manière, on pourrait soutenir qu'à l'opposé de Tanizaki, elle cadenasse le texte, en faisant taire sa part de parole vive, pour en faire le lieu d'une écriture de la maîtrise, d'un récit sous contrôle. On peut lire là le souci de juguler ce qui peut paraître déborder les catégories clairement établies ou en cours d'établissement, dans le traitement de la subjectivité ou des personnes narratives. Il y a, à cet égard, une forme de censure de la voix dans le texte de Yosano. De cette censure, on peut proposer plusieurs explications; l'une serait que cette voix réduite au silence relèverait d'une oralité considérée comme prémoderne, que le roman comme genre a dû, à un moment de l'histoire littéraire, étouffer, pour devenir justement genre. En somme, la traduction Yosano, du point de vue matériel comme du point de vue narratif, se présente comme celle qui est la moins soucieuse de la restitution du passé ; elle transpose franchement, ce qui lui permet certainement d'investir le plus aisément une forme romanesque moderne. Chez Yosano Akiko, le Genji monogatari devient, en somme, un roman de Yosano Akiko ; et le fait qu'elle puisse recourir largement à des shingo prouve qu'elle n'a aucun modèle à reproduire.

Les deux tentatives évoquées jusqu'à présent exercent, dans la radicalité de leur démarche, un pouvoir de fascination. Mais le lecteur ne peut s'empêcher d'avoir le sentiment qu'à bien des égards, les choix qui les déterminent sont dictés plus - ou au moins autant - par des considérations littéraires générales que par une attention portée au Genji Monogatari en tant que tel.

Par son choix stylistique d'une narration en -desu/-masu, la version Setouchi se rapproche plus de la version Tanizaki que de la version Yosano. Toutefois, la préoccupation de reconstituer un univers narratif n'y a guère de place. Ainsi Setouchi n'hésite pas à recourir largement aux discours directs entre crochets - donc à injecter une modalité énonciative très anachronique, et à mettre dans la bouche des 
personnages des propos qu'ils n'ont, à la lettre, jamais tenus... D'une manière générale, la traduction est parfois à la limite de l'adaptation ou de la glose; le vocabulaire est souvent moderne, les kango sont nombreux, les personnages (et donc les lecteurs) ne se perdent pas dans les méandres de la subjectivité des personnages. Tout se passe donc comme si la modernité autorisait que l'on prenne autant de libertés qu'il paraît nécessaire en fonction d'une représentation à la fois des attentes des lecteurs d'aujourd'hui et de leur capacité de compréhension. Dans une sorte de préface à la nouvelle présentation de sa traduction, Setouchi décrit ainsi son propos :

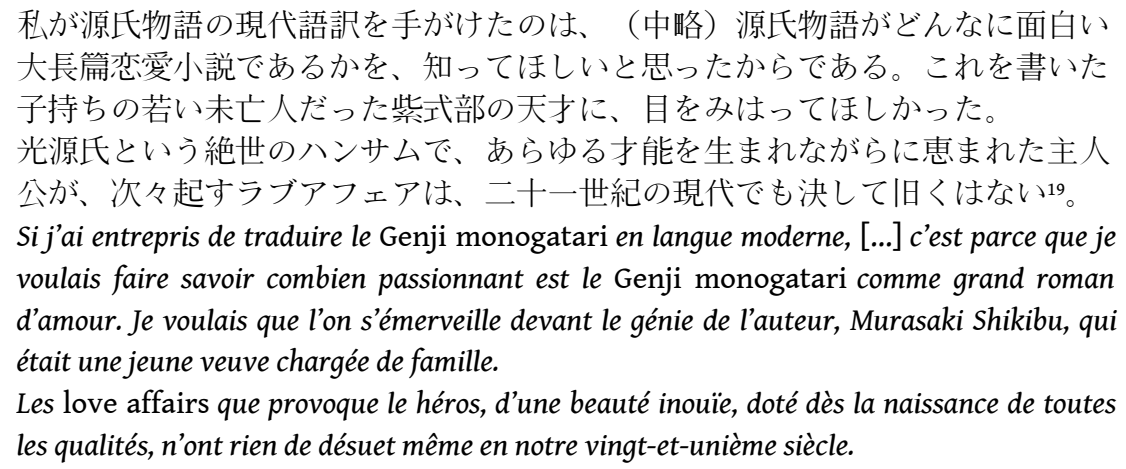

Les intentions de Setouchi sont claires : il s'agit de donner aux lecteurs la version la moins dépaysante du Genji, de leur faire retrouver dans ce texte, mais au superlatif, ce qu'ils peuvent aimer dans la littérature sentimentale. Le jugement que le lecteur se forgera devant cette traduction dépendra donc en définitive de ses propres représentations de ce que peut être la lecture aujourd'hui d'un classique.

Venons-en alors à la traduction Enchi. Ses choix énonciatifs ont ceci de particulier qu'ils induisent une sorte de variation de la distance focale, avec un narrateur qui tient parfois le texte et les événements de l'histoire à distance, et qui parfois se met à s'en rapprocher très fortement. Ces variations peuvent se produire d'un paragraphe à l'autre, mais aussi à l'intérieur d'un même paragraphe, voire même à l'intérieur d'une seule phrase comme le montre la première phrase du chapitre Suma. Le lecteur a le sentiment d'assister aux déplacements d'un narrateur qui entre et sort à sa guise de l'histoire et qui, de ce fait, marque fortement son rôle de meneur de récit alors même qu'il ne fait pas entendre de parole : le texte n'est pas en -desu/-masu, la narration ne passe pas par la reconstitution d'une énonciation. Du coup, dans la version Enchi, le narrateur peut se permettre d'intervenir et d'ajouter des éléments dans le texte ${ }^{20} . \mathrm{Si}$ l'on reprend la première phrase d'incipit,

世にあるのがひどく煩わしく、耐えきれないようなことばかりつもってくるの
で、源氏の君は、この上、強いて知らぬ顔を作って京に暮らしていても、今よ
りもっと恐ろしい事態が起ってくるかもしれな、遠流などの恥を見ないうち
に自ら京を退去して、政治に望みを持たぬことを、潔く天下に示したほうがよ
いとお考えになるようになった。

toute la partie soulignée est un ajout du narrateur qui, profitant de sa position de narrateur omniscient, se glisse dans l'esprit du personnage pour donner un aperçu plus circonstancié de ses méditations. Un narrateur omniscient qui ne recule devant rien, pourrait-on dire... Mais Enchi Fumiko s'explique de ce choix dans la préface de sa traduction.

桐壶の更衣, 光源氏、藤盇の宮、六条の御息所，空蝉などの内部に立ち入っ

て、本文では美しい紗膜 (ママ)のうちに朧ろに霧りかすんでいる部分に証明を

与えているのは、私自身が「源氏」を読んでいるうちに自然にそこまでふくら

んでいかなけ枕なららなかった止むを得ない膨張なのであって、こうした加筆 
を古典に対する礼を失した態度と見る読者もあるかもしれない。しかし、私

は、奇を衒ったり、原作を歪曲したりするためにこの加筆を行なったのではな

い。「源氏」を読んでいる間に、それらの部分にくると、いつも憑かれたよう

に自分のうちに湧き立ち、溢れたぎり、やがて静かに原文の中に吸収されてゆ

く情感をそのまま言葉に移して溶かし入れなければいられないままにそうした のである。その点、私にとっては、この現代語訳は、加筆の部分も含めて、原 作への純粋な愛の表現であることに何の後ろめたさも感じない21。

Si, pénétrant dans l'inimité de la dame de Kiritsubo, du Prince Genji, de la dame de Fujitsubo, de la dame de Rokujō, d'Utsusemi, j'apporte un éclairage dans ces recoins qui, dans le texte original, demeurent enrobés de brume et cachés derrière un magnifique voile, ce sont là des expansions inévitables qui se sont produites alors que je lisais moi-même le Genji, et certains lecteurs considéreront peut-être ces ajouts comme des offenses à l'égard de ce classique. Mais je n'ai pas procédé à ces ajouts pour me singulariser, ou pour pervertir l'original. Alors que je lisais le Genji, lorsque j'arrivais à ces passages, comme si j'étais possédée, des sentiments surgissaient en moi, débordaient pour ensuite être absorbés doucement par le texte original, et je ne pouvais faire autrement que les transposer en mots pour les couler dans la traduction. Et de ce point de vue, ma traduction en langue moderne, expression, jusque dans les ajouts, de l'amour désintéressé que je porte à l'original, ne suscite en moi aucune mauvaise conscience.

Irrespect pour irrespect, autant choisir la voie qui permet au texte de se voir insuffler une nouvelle vie, ce qui se produit au moment où le narrateur - double ici de l'auteur s'est vraiment approprié non pas le texte dans sa lettre, mais, plutôt, son univers romanesque. Du point de vue de l'usage que fait Enchi des mots, son utilisation de lectures ajoutées, rubi ルビ, surimposant des termes tirés du lexique indigène, wago ou yamatokotoba 和語, à des kango, pourrait confirmer cette approche. Ainsi, le mot seiji 政 治 se voit-il doté de rubi incitant le lecteur à lire ici matsurigoto. Selon Kitamura, cet usage des rubi serait une manière de concilier le respect de l'évocation de Heian qui passe par les wago, et un mode de réception contemporain des textes fondé sur la lecture comme approche visuelle des mots, les kango ayant à cet égard plus d'impact que les yamatokotoba. De ce point de vue, et quel que soit l'attachement que l'on puisse avoir pour les autres versions, si on considère la réussite ou l'échec d'un saisei, d'une régénération ou d'une accession à une nouvelle vie, c'est sans doute la tentative d'Enchi qui est la plus convaincante et qui parvient au mieux à trouver un équilibre entre le fait qu'il s'agisse à la fois d'un texte d'aujourd'hui, et d'un classique - parce qu'il est véritablement assumé, réapproprié, par un lecteur d'aujourd'hui.

Dans la préface de sa version, Enchi Fumiko s'interroge sur ce que signifie le fait de traduire un classique aujourd'hui. Indépendamment des réussites ou des échecs, et comme Enchi le laisse d'ailleurs entendre, c'est précisément le fait qu'un texte fasse l'objet de réappropriation à chaque époque qui le constitue en tant que classique. C'est aussi, il ne faut pas l'oublier, une ouverture de sens. Un texte, dit-on souvent, et disent en particulier les traducteurs, est fait de lui-même mais aussi de toutes les traductions passées, présentes et futures, qui déploient peu à peu et patiemment les significations qu'il porte. Ce qui est vrai de tout texte l'est a fortiori pour un classique, fondamentalement fécond et engendrant toutes sortes d'autres lui-même, pré-texte devenant prétexte pour le plus grand profit de la littérature. On peut donc pour conclure se livrer à un petit exercice de littérature fiction : un jour peut-être, les textes, les versions auxquelles nous nous sommes intéressés ici, seront devenus des éléments d'un ensemble plus vaste, d'ailleurs assez disparate, qui sera alors le Genji monogatari. Et en ce sens, le destin de toutes nos versions contemporaines, s'il leur est donné de survivre, ne consiste-t-il pas, en définitive, à devenir des variantes? 


\section{ANNEXES}

(Pour chaque version est indiqué le nom de l'auteur, la tomaison suivie de la page ; l'original est cité dans la leçon donnée dans Shōgakukan Nihon koten bungaku zenshū, Genji monogatari, vol. 2, 1972, noté NKBZ)

\section{Annexe 1 : Incipit du chapitre Suma}

(NKBZ, p. 153)

世の中いとわづらはしく、はしたなきことのみまされば、せめて知らず顔にあり 経ても、これよりまさることもやと思しなりぬ。かの須磨は、昔こそ人の住多処 などもありけ机、今はいと里ばなれ心すごくて、海人の家だにまれになど聞きた まへど、人しげく、ひたたけたらむ住まひは、いと本意なかるべし、さりとて、 都を遠ざからんも、古里おぼつかなかるべきを、人わるくぞ思し乱るる。

よろづの事、来し方行く末思ひつづけたまふに、悲しきこといとさまざまなり。

うきものと思ひ棄てつる世も、今はと住み離れなんことを思すには、いと棄てが たきこと多かる中にも、姫君の明け暮机にそへては思ひ嘆きたまへるさまの心苦 しうあはれなるを、行きめぐりてもまたあひ見むことを必ずと思さむにてだに、 なほ一二日のほど、よそよそに明かし暮らすをりをりだに、おぼつかなきものに おぼえ、女君も心細うのみ思ひたまへるを、幾年そのほどと限りある道にもあら ず、逢ふを限りに隔たり行かんも、定めなき世に、やがて別るべき門出にもやと いみじうおぼえたまへば、忍びてもろともにもやと思し寄るをりあれど、さる心 細からん海づらの波風よりほかに立ちまじる人もなからんに、かくらうたき御さ まにてひき具したまへらむもいとつきなく、わが心にもなかなかもの思ひのつま なるべきをなど思し返すを、女君は「いみじからむ道にも、おくれきこえずだに あらば」とおもむけて、恨めしげにおぼいたり。

（与謝野/上 366 ）

当帝の外戚の大臣一派が極端な圧迫をして源氏に不愉快な目を見せることが多く なって行く。つとめて冷静にはしていても、このままで置けば今以上な禍いが起 こって来るかもしれぬと源氏は思うようになった。源氏が隠棲の地に擬している 須磨という所は、昔は相当に家などもあったが、近ごろはさびれて人口も稀薄に なり、漁夫の住んでいる数もわずかであると源氏は聞いていたが、田舎といって も人の多い所で、引き締まりのない隠棲になってしまってはいやであるし、そう かといって京にあまり遠くては、人には言えぬことではあるが夫人のことが気が かりでならぬであろうしと、煩悶した結果須磨へ行こうと決心した。この際は源 氏の心に上ってくる過去も未来も皆悲しかった。いとわしく思った都も、いよい よ遠くへ離れて行こうとする時になっては、捨て去りがたい気のするものの多い ことを源氏は感じていた。その中でも若い夫人が、近づく別れを日々に悲しんで いる様子の哀れさは何にもまさっていたましかった。この人とはどんなことが あっても再会を遂げようという覚悟はあっても、考えてみ机ば、一日二日の外泊 をしていても恋しさに堪えられなかったし、女王もその間は同じように心細がっ ていたそんな間柄であるから、幾年と期間の定まった別居でもなし、無常の人世 では、仮の別れが永久の別れになるやも計られないのであると、源氏は悲しく て、そっといっしょに伴って行こうという気持ちなることもあるのであるが、そ 
うした叔しい須磨のような所に、海岸へ波の寄ってくるほかは、人の来訪するこ ともない住居に、この華麗な貴女と同棲していることは、あまりに不似合いなこ とではあるし、自身としても妻のいたましさに苦しまねばならぬであろうと源氏 は思って、それはやめることにしたのを、夫人は、

「どんなひどい所だって、ごいっしょでさえあれば私はいい」

と言って、行きたい希望のこばまれるのを恨めしくおもっていた。

（谷崎／二7）

世の中がたいそう面倒に、居心地の悪いことばかりが殖えて来ますので、努めて 平気を装って行くにしても、今にこれ以上の目に遭うようなこともと、思うよう におなりになりました。

あの須磨は、昔こそ人の住家などもありましたものの、今はたいそう人里を離れ た、荒れ果てた感じになっていまして、海人のいえさえ稀であると聞いておいで になりますけ扎ども、あまり人の出入りの激しい、賑やかなあたりに住むのは本 意ではありません。そうかといって都を遠く離れるのも、故郷のことが気にかか るであろうと、人聞きが悪いほどお迷いになります。来し方のこと、行く末のこ と、よろずのことをお思いつづけにになりますと、悲しいことが実にいろいろと あるのです。どうせ憂きものと思い捨ててしまった世の中も、いよいよ離れてし まおうとお思いにな机、なかなか未練の出ることが多い中でも、あの姫君が明 け暮れに添えて嘆いていらっしゃる御様子のいとおしさは、何ものにもましてい じらしいのです。いったんは別れても再びめぐり逢うことが間違いないと分かっ ていらっしゃってさえ、ほんの一日二日の間別々にお暮らしなさる折々でさえ、 心配なように感じられ、女君も心細いようにばかりお思いになりますのに、幾年 という期限の定まった旅でもなく、「逢尔をかぎり」に隔たって行きますのも、 無常の世のことゆえそれがそのまま永の別机の門出にもなろうかと、とても悲し くお思いになりますので、いっそこっそり連れて行こうかなどとお考えになる折 もありますけれども、そういう物叔しい海浜に、波風よりほかにおとなう者もな いような所へ、こんな可憐な姫君をお連机になるのも不似合いであるし、御自分 としてもかえって気苦労の種となろうなどとお思い返しになりますのを、女君 は、「たとい死出の旅路であろうと、御一緒に参拉すことならば」とお漏らし になって、恨めしそうにしていらっしゃるのでした。

(円地/二9)

世にあるのがひどく煩わしく、耐えきれないようなことばかりつもってくるの で、源氏の君は、この上、強いて知ら始顔を作って京に暮らしていても、今より もっと恐ろしい事態が起ってくるかもしれない、遠流などの恥を見ないうちに自 ら京を退去して、政治に望みを持ためことを、絜く天下に示したほうがよい、と お考えになるようになった。

あの須磨という所は、昔こそは人の住む家などもあったようであるが、今は大そ う里離れて、もの凄いほど荒れてしまい、海人の苫屋さえ稀にしかないとお聞き になるにつけて、また今の場合、人の出入りが多くざわざわと落ちつかない住居 は、わが本意にも叶うまい。それよりはいっそとお考えになるものの、さりとて 都から遠ざかるとなれば、また故郷のことが心にかかるに違いないと、未練にあ れこれ思い乱れておいでになる。

よろずのことにつけて、はなやかであった昔とこれから先の暗い将来をお思いつ づけになると、お心に沁みて悲しいことがさまざまあるのだった。辛い、くるし いものと諦めをつけてしまったはずの世の中にも、いよいよ遠くへ行き離机よう と思えば、やはり捨てがたい絆が数々ある。中にも、ご一緒にいられる対の女 
君、朝夕にお嘆きになる御様子は、何にも増さっていとしくあわ机思されるの であった。必ずまた逢えるとわかっていながらも、ほんの一日二日離れて暮らす のでさえ、あやしく心にかかり、女君も心細くばかり思って君を頼っていられた のに、今度こそ何年経ったら帰ると当てのある旅でもない。再び逢う日を頼みに して隔たって行ってしまっても、定めない憂き世では、やがて、そ执永別の門 出にもなりか权まいと梁く思い入るにつけて、いっそ女君をひそかに連机て行こ うかとお思いよりになることもある。しかし、そんなにももの淋しい海辺の、波 風よりほかには立ち交じる人もないような所に、こんななよやかな愛らしい方を 連れていらっしゃるのも、まことにふさわしくないことであるし、君御自身のお 心にも、いっそう物思いを増す種となろうと思い返される。女君は「どんなに辛 い恐ろしい道でも、君と御一緒でさえあ机ば」としきりにお心を历めかして、一 人でお立ちになるのを恨めしげに思っておいでになる。

(瀬戸内 $/$ 三 6 )

世の中の情勢がたいそう不穏になり、源氏の君は立つ瀬もないほど情けなく厥な ことばかりが多くなってきます。つとめてそ知ら顔をし平静を装っていても、 今にこれよりももっと恐ろしい事態がおこるかもしれない、と感じるようになり ました。

それならいっそ、流罪などという辱めを受ける前に自分から都を離れ、遠くへ 行ってしまおうとお考えになります。

「あの須磨というところは、昔こそ人の住家などもあったようだが、今は、すっ かり人里離れてもの淋しく荒れはてて、海人の家さえほとんど見られない」と か、お聞きになりましたけれど、

「あまりひとの出入りの多いうるさい所に住むのは、この際、本意ではない。か といって、都をすっかり遠く離れてしまうのも、かえって故郷の都のことがさぞ かし気にかかることだろう」と、源氏の君は、あれこれ見苦しいほどお迷いにな ります。

Traduction René Sieffert (Le Dit du Genji, tome 1, Presses Orientalistes de France, 1999, p. 247) :

Sa position était fort délicate et ne faisait que s'aggraver, aussi en venait-il à se dire que s'il s'obstinait à demeurer à la Ville en feignant l'indifférence, il pourrait bien lui arriver pis encore.

Il avait ouï dire de Suma que jadis, certes, des gens de qualité en avaient fait leur retraite, ce n'était plus à présent qu'une effroyable solitude, loin de tout lieu habité, où les maisons de pêcheurs même étaient clairsemées ; mais un lieu fréquenté, où on l'eût remarqué, n'eût du tout convenu à son dessein. Malgré cela, il se tourmentait vilainement à l'idée que, s'il s'éloignait de la capitale, l'inquiétude le rongerait de ce qui pourrait y advenir. Qu'il évoquât le passé ou qu'il songeât à l'avenir, ce n'était partout que raisons diverses de s'affliger.

\section{Annexe 2 :}

- (NKBZ, p. 185)

ことや、騷がしかりしほどの紛れに漏らしてけり。かの伊勢の宮へも御使ありけ り。 
(与謝野 /上 3889 )

源氏が須磨へ移った初めの記事の中に筆者は書き漏らしてしまったが伊勢の御息 所のほうへも源氏は使いを出したのであった。

（谷崎／二36）

そういえば、つい駊がしいことにまぎれて書き漏らしていました。あの伊勢の宮 へもお使いをお差立てになったのでした。

（円地／二39）

そう言えば、何かと騒がしかった間の紛れに語り洩らしてしまったが、あの伊勢 に下られた御息所の御在所へもお使いが立ったのであった。

（瀬戸内／三4 2)

ほんにそう言えば、つい何かと騷がしかったことに取りまぎれて、話し落として おりました。

あの伊勢の斎宮にも、お手紙を届けにお使いをさし向けられたのでした。

Traduction René Sieffert (op.cit., p. 263) :

Mais au fait, dans tout ce tumulte, j'avais omis de le noter : chez cette Princesse qui était en Isé, il avait de même envoyé un messager.

\section{Annexe 3 :}

$\checkmark$ (NKBZ, p. 204)

須磨には、年かへりて日長くつれづれなるに、植急し若木の桜ほのかに咲きそめ て、空のけしきうららかなるに、よろづのこと思し出られて、うち泣きたまふを り多かり。二月二十日あまり、去にし年、京を別れし時、心苦しかりし人々の御 ありさまなどいと恋しく、南殿の桜盛りになりぬらん、一年の花の宴に、院の御 気色、内裏の上のいときよらかになまめいて、わが作机る句を誦じたまひしも、 思ひ出できこえたまふ。

いつとなく大宮人の恋しきに桜かざししけふもきにけり

(与謝野／上４０2）

須磨は日の永い春になってつれづれを覚える時間が多くなった上に、去年植えた 若木の桜の花が咲き始めたのにも、霞んだ空の色にも京が思い出さ机て、源氏の 泣く日が多かった。二月二十幾日である、去年京を出た時に心苦しかった人たち の様子がしきりに知りたくなった。また院の御代の最後の桜花の宴の日の父帝、 艶な東宮時代の御兄陛下のお姿が思われ、源氏の詩をお吟じになったことも恋し く思い出された。

いつとなく大宮人の恋しきに桜かざしし今日も来にけり

と源氏は歌った。

（谷崎／二 55 ）

須磨では年が改まり、日が長くて、つれづれな頃となりましたが、植えておかれ た若木の桜がちらほらと咲きそめ、空のけしきがうららかなので、いろいろのこ とが偲ばれ給うて、お泣きになる折々が多いのでした。二月の二十日あまりに は、去年都を別れた時にいとおしくお思いになった方々のおん有様などがたいそ う恋しく、南殿の桜はちょうど今が盛りであろう、一年の花の宴に、故院の御機 嫌が麗しく、今の帝がたいそうきよらかに優雅な御様子で、自分が作った詩の句 を誦じ給うたのになどとお思い出しになります。 
いつとなく大宮人の恋しきに

桜かざししけふもきにけり

$$
\text { （円地／二 } 57 \text { ） }
$$

須磨では年も改まって、日も長くなりはじめ、つれづれなうちに、去年植えた若 木の桜もちらほら咲き始めた。空の様子のうららかさにつけても、君はさまざま のことが思い出られて、おもわず淚ぐみ給う折が多いのであった。

二月二十日過ぎ、去年京を離れた折に、不憫でならなかった女たちの御様子など もそれぞれに恋しく思われるし、また、南殿の桜も今花盛りであろう、いつぞや の花の宴の折に、御父帝の御機嫌麗しかった御有様、その頃東宮であらせられた 今の主上が、大そう清らかに奥ゆかしい御様子で、自分の作った詩を詠いあげて 下さったことなどもしみじみ思い出でられる。

いつとなく大宮人の恋しきに

桜かざしし今日も来にけり

$$
\text { （瀬戸内／三6 } 3 \text { ） }
$$

須磨では、年も改まり、日も次第に長くなって所在のない折から、去年植えた若 木の桜もちらほら咲き始めました。空の様子もうららかでのどかなのを御覧にな るにつけ、源氏の君は、さまざまのことを思い出されて、つい、泣いておしまい になることが多いのでした。

二月二十日過ぎには、去年都を離れてきた時、別れ難く不憫に思った女君たちの 御有り様などが、たいそう恋しくて、宮中の南殿の桜も今頃は花盛りになってい るだろう。先年の花の宴の折の、故桐壶院の御機嫌麗しかった御様子、まだ東宮 であられた今の帝の、大そうお美しく優雅でいらっしゃって、自分の作った詩句 をお吟じになられたことだった、などと、それからそれへとお思い出しになられ るのでした。

いつとなく大宮人の恋しきに

桜かざしし今日も来にけり

Traduction René Sieffert (op.cit., p. 275)

À Suma cependant, la nouvelle année venue, le Prince se morfondait au long des jours ; le jeune cerisier qu'il avait planté commençait à fleurir timidement, et le ciel lumineux éveillait en lui mille souvenirs qui, plus d'une fois, firent couler ses larmes. Passé le vingt de la deuxième lune, à l'heure où l'an dernier il avait quitté la Ville, il ressentit plus cruellement encore l'absence de celles dont il s'était éloigné à grand-peine ; les cerisiers du Pavillon du Sud devaient être dans toute leur splendeur ; il revoyait l'image de l'Empereur retiré, lors du banquet aux fleurs de l'autre année, et la noble prestance de l'Empereur actuel quand il avait déclamé les poèmes que lui-même avait composés.

Quand à tout instant des habitants du Palais déjà je languis voici revenu le jour où de fleurs me couronnai

\section{NOTES}

1. En dehors de la version en langue moderne qui figure dans l'édition Nihon koten bungaku zenshū de Shōgakukan (1972) que l'on doit à Abe Akio 阿部秋生, Akiyama Ken 秋山虔 et Imai 
Gen.ei 今井源衛, l'une des plus célèbres est celle de Tamagami Takuya 玉上玩彌, publiée chez Kadokawa en 1964 et reprise en édition de poche dans la collection Kadokawa Sofia bunko.

2. On parle ainsi du Yosano Genji, ou du Tanizaki Genji; et la version de poche de la traduction Tanizaki est intitulée Jun.ichirō yaku Genji monogatari (Le Genji Monogatari traduit par Jun.ichirō).

3. Pour mémoire, il existe une traduction du Genji par Funabashi Seiichi 船橋聖一 (publiée en 1976 chez Heibonsha), une autre par Tanabe Seiko 田辺聖子 (publiée en 1979-1980 chez Shinchōsha), une traduction - ou peut-être faudrait-il parler ici plutôt d'une adaptation - par Hashimoto Osamu 橋本治 intitulée Yōhen Genji Monogatari 羔变源氏物語 (publiée en 1991-1992 chez Chūō kōron sha).

4. Que les traductions savantes puissent parfois faillir à leur mission est un autre problème; de jure, elles sont supposées proposer à la lecture le dispositif nécessaire pour le rendre clair.

5. On sait que Yosano a par ailleurs rédigé un commentaire du Genji, mais tout le texte à l'exception d'une page a disparu en 1923, lors du grand tremblement de terre du Kantō. Cf. Gaye Rowley, “Textual Malfeasance in Yosano Akiko's Shin'yaku Genji monogatari”, Harvard Journal of Asiatic Studies, vol. 58, n 1, juin 1998, p. 218 ; Claire Dodane, Yosano Akiko, poète de la passion et figure de proue du féminisme japonais, Publications Orientalistes de France, 2000, p. 272.

6. Le poème est repris dans l'annexe 3 , en fin d'article.

Je remercie Michel Vieillard-Baron pour la traduction de la version originale des poèmes en langue classique ; la traduction des versions modernes est de mon fait.

7. Enchi Fumiko yaku, Genji Monogatari, vol. 2, Shinchō bunko, 1980, p. 57.

8. Ibid., p. 69.

9. Le glossaire se termine en effet sur la mention « Fait par Takagi Kazuko » (Sakusei Takagi Kazuko 作成高木和子) sans qu'aucune indication ne soit donnée où que ce soit sur cet auteur.

10. Setouchi Jakuchō yaku, Genji Monogatari, vol. 3, Kōdansha, 2001, p. 66 (édition dite shinsōban, « nouvelle présentation »).

Le poème de Murasaki no ue du chapitre Akashi devient (ibid., p. 77) :

はるかな須磨の浦風は

どんなにはげしく吹くことやら

あなたを思い遠くから

泣き暮らす涙の波にこの袖が

乾く閑なく濡らされて

Le vent dans la baie de Suma lointaine

Avec quelle force ne souffle-t-il pas

Je pense à vous de si loin

Par les vagues de larmes que je ne cesse de verser ma manche

Est trempée sans avoir le temps de sécher

11. Jun.ichirō yaku, Genji Monogatari, vol. 3, Chūkō bunko, 1973, p. 55.

12. Voir par exemple Gaye Rowley, op. cit., p. 201-219; Midorikawa Machiko, "Coming to Terms with the Alien - Translations of Genji Monogatari", Monumenta Nipponica, vol. 58, n² 2, été 2003, p. 193-222.

13. Kitamura Yuika 北村結花, «Genji Monogatari no saisei - Gendaigoyaku ron 「「源氏物語」の再 生一現代語訳論」」 (Faire renaître le Genji Monogatari - théorie des traductions en langue moderne)», 文学 Bungaku, vol. 3, nº 1, hiver 1992, p. 44-54.

14. Kitamura, op. cit., p. 45.

15. À la différence, donc, de l'interlocuteur présent dans le texte de Tanizaki. Nous n'abordons pas ici la question, largement débattue en théorie narratologique, de l'instance destinataire, de type lecteur impliqué, présente ou non dans le dispositif textuel.

16. Ce qui, au demeurant, est tout à fait conforme à l'un des ses principaux objectifs romanesques : inventer des narrateurs singuliers dont la parole produit le récit (voir Manji [Svastika], Mōmoku monogatari 盲目物語 [Récit d'un aveugle], etc.) 
17. Sur le monogatari, voir Jaqueline Pigeot, " Autour du monogatari : questions de terminologie », Cipango, $\mathrm{n}^{\circ}$ 3, novembre 1994, p. 93-107.

18. La question demeure d'ailleurs entière pour l'original - faut-il lire le Genji Monogatari, ou peut-être tout monogatari, comme un texte écrit ou comme un texte proféré ? Quelle est la convention de lecture en la matière ? - mais elle dépasse notre propos.

19. Setouchi, op.cit., p.1. La bande du livre porte l'accroche publicitaire 最高のラブストー リー、 « La plus belle des love stories».

20. Ce que signale aussi par exemple Kitamura.

21. Enchi Fumiko, op. cit., vol. 1, p. 7.

\section{RÉSUMÉS}

La traduction d'une œuvre classique en langue moderne est ambivalente: elle confirme son statut de classique mais fait naitre une œuvre nouvelle, fonction des intentions du traducteur. Sont ici étudiées quatre traductions « littéraires» marquantes réalisées par trois romanciers et une poétesse.

Translation of classic works into modern language is quite ambivalent: it reinforces its status, but produces a new work, due to the translator's aim. Study of four significant "literary" translations, by three novelists and a poet.

\section{INDEX}

Thèmes : littérature, traductologie

キーワード : Genji monogatari 源氏物語, gendaigo 現代語, Genji monogatari -- bājon 源氏物 語・バージョン, Murasaki Shikibu 紫式部 (v. 973-v. 1014 ou 1025), Setouchi Jakuchō 瀬戸内寂聴 (1922-), hon.yaku 翻訳, gendaigo yaku 現代語訳, Heian jidai 平安時代（794-1185), bungaku 文 学, hon.yaku kenkyū 翻訳研究

Mots-clés : Dit du Genji, Setouchi Jakuchō (1922-), Genji monogatari -- versions, Murasaki Shikibu (v. 973-v. 1014 ou 1025), traduction

Keywords : Genji monogatari - Translations, Genji monogatari - Versions, Heian, Literature, Tale of Genji, Murasaki Shikibu (v. 973-v. 1014 or 1025), Translating and Interpretation, Translation Studies, Translators

Index chronologique : Heian 